\title{
Metal contamination pathways of a restored marshland in an industrial estuary
}

\author{
Francisco J. Artigas ${ }^{1,2} \cdot$ Ying Yao $^{1,2}$ (1) $\cdot$ Joseph Grzyb ${ }^{1} \cdot$ Yefim Levinsky $^{1}$
}

Received: 7 July 2020 / Accepted: 22 September 2020 / Published online: 6 October 2020

(c) Springer Nature Switzerland AG 2020

\begin{abstract}
Contaminated surface sediments were removed from a coastal marsh and replaced with clean engineered sediments before marsh vegetation was replanted and the site was reopened to the tide. Differences in trace metal concentrations $(\mathrm{Cd}, \mathrm{Cr}, \mathrm{Cu}, \mathrm{Fe}, \mathrm{Hg}, \mathrm{Mn}, \mathrm{Ni}, \mathrm{Pb}, \mathrm{Zn}$ ) were monitored for 11 years at different sediment depths, under two types of engineered sediments (with and without compost), and at three marsh surface elevations. Except for $\mathrm{Hg}$ and $\mathrm{Cd}$, all others followed the patterns of Fe and $\mathrm{Mn}$ of decreasing concentration during drought years and increasing concentration during wet years. Metals in deep sediments $(>25 \mathrm{~cm})$ are always higher than on the surface. Surfaces higher in the terrain had fewer metal concentrations compared to lower elevations. The compost treatment had no insignificant effect on metal concentration. The main pathways involved in remobilization from the buried legacy sediments are organic metal complexation, reductive dissolution, and oxidation of metal sulfides. $\mathrm{Hg}$ showed an enrichment pattern throughout the study period suggesting atmospheric deposition as the main pathway. Similarly, sources of $\mathrm{Cd}$ are most likely from atmospheric wet deposition since most of the $\mathrm{Cd}$ variation is explained by changes in the amounts of rain. Metal concentration in the sediments decreased up to $50 \%$ from pre-restoration conditions; the only exceptions were $\mathrm{Hg}$ and $\mathrm{Cd}$ which continue to accumulate. Increasing dry periods and storm frequencies from changing global weather patterns have the potential to create conditions for greater bioavailability of metals from this and similar world estuaries.
\end{abstract}

Keywords Restoration · Sediments · Metals · Pathways · Coastal marsh

Mathematics Subject Classfication $91 \mathrm{~B} 76$

JEL Classification Q53

\section{Introduction}

More frequent and stronger storms is impacting coastal areas and industrialized estuaries around the world and threatening the ecological services marshlands provide [1]. New thinking in shoreline management is shifting from building massive coastal barriers to allowing floodwater from big storms to inundate predetermined areas, to prevent the flooding of developed areas [2]. In estuaries with a history of industrial pollution, increased frequency of storms, sea-level rise and the reopening of low lying areas to the tides can increase the bioavailability of legacy metals buried in the sediments [3]. Marshlands of industrialized estuaries act as sinks of metals [4]. They are adsorbed into organic and inorganic particulates and find their way up tidal creeks and marsh surfaces where they accumulate [5]. Once buried, $\mathrm{H}_{2} \mathrm{~S}(\mathrm{aq}), \mathrm{Fe}^{2+}$ and dissolved organic carbon (DOC) have a significant effect on their mobility [6].

Ying Yao, cyao@njsea.com | ${ }^{1}$ Meadowlands Environmental Research Institute, New Jersey Sports and Exposition Authority, Lyndhurst, NJ 07071, USA. ${ }^{2}$ Rutgers University, Department of Earth and Environmental Science, Newark, USA. 
In most tidal systems, contamination from the 1950s and 1960s is buried about $30 \mathrm{~cm}$ deep in the sediments [7]. It is a known practice not to disturb these sediments. Undisturbed anoxic sediment promotes metal sulfide precipitation and increases metal stability against reoxidation and remobilization [8].

Examples of estuarine metal contamination worldwide include the Scheldt River estuary in the Netherlands where high levels of trace metals associated with the finer sediment fractions have known anthropogenic sources [9]. The Yangtze River estuary has naturally occurring trace metals, and near Shanghai, high copper and cadmium levels are easily traced back to industrial and agricultural activities [10]. Anthropogenic sources of trace metals also exist in the Ganges river in India which contributes a disproportional amount of dissolved metals to the Ganges estuary [11]. Studies in the Thames River estuary by Pope and Langston (2011) found that trace metals in sediments routinely exceed the established criteria and in most cases are bioavailable [12]. Similar studies in Spain by Morillo and Usero (2008) in Algeciras Bay and Huelva estuary report high levels of metals that were also positively correlated with concentrations in nearby test organisms [13]. Recent studies of the mechanisms involved in the fate of metals in estuarine systems seek to determine how grain size and point sources contribute to enrichment levels [14-17]. Other studies look at the partitioning between dissolved and particulate fractions with organic matter, aluminum, iron, clay minerals, and sulfides $[5,18,19]$. In North America, the establishment of sediment regulatory guidelines in the 1970s prompted studies on risk assessment, pollution indices, and reporting on the levels of metals in marine sediment compared to established criteria [10, 19-21].

The Meadowlands of New Jersey (Fig. 1) has a long history of environmental impacts [22-27]. Overlooking industrial parks and transportation corridors, the Meadowlands marshlands are interspersed among maritime terminals, warehousing complexes, power plants, and high-density residential. They are the first line of defense to hold waters back against rising tides and floods. With climate change and rising sea levels, there are concerns among residents, regional and city planners, and wildlife managers about the long-term fate of metals and their possible impact on human health, ecosystem health, and property values. In North America, the Clean Water Act of the 1970s had the effect of removing many known point

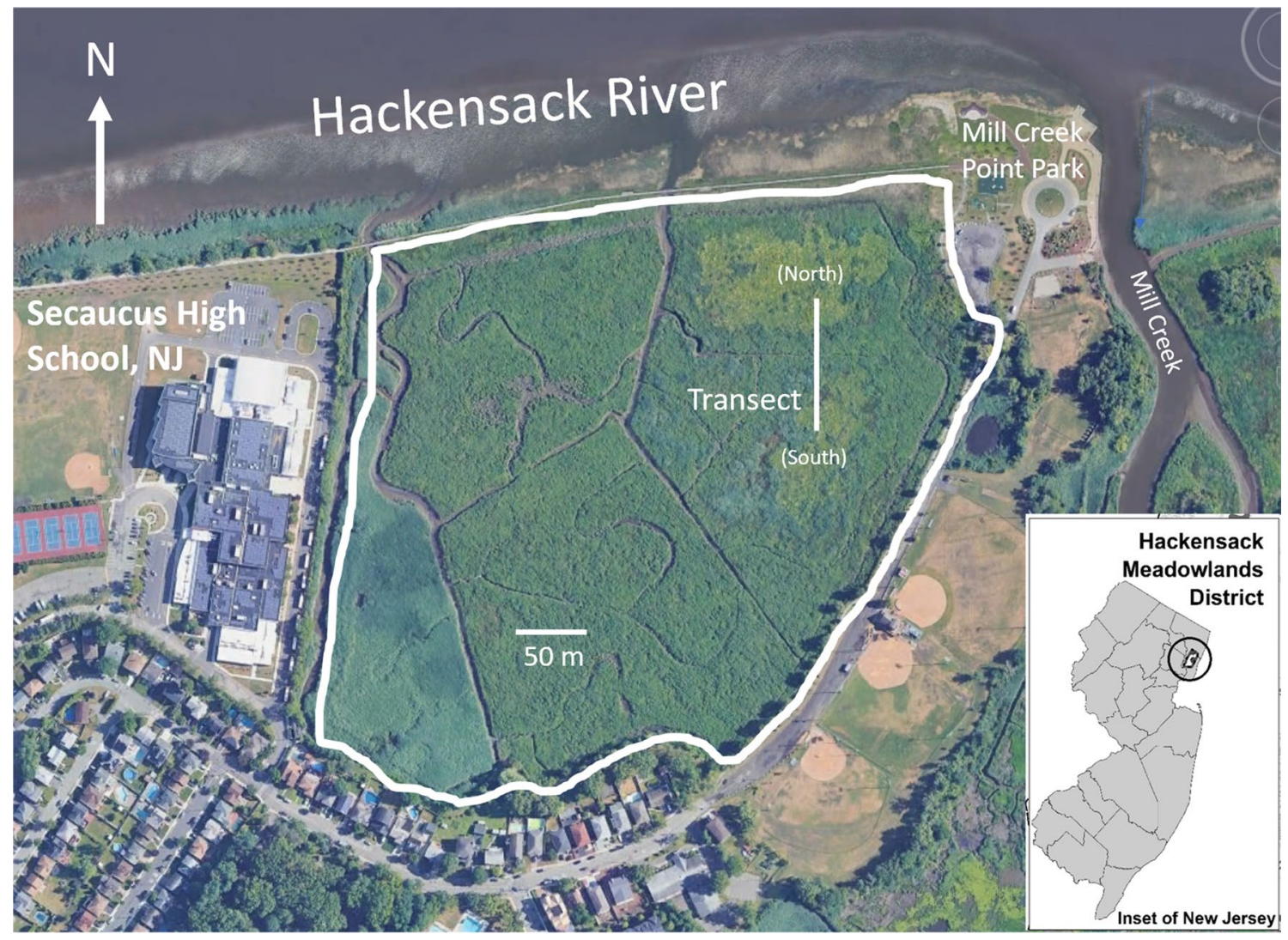

Fig. 1 Location of the study site along the Hackensack River and by the Town of Secaucus (adjacent to Secaucus High School) in New Jersey. The map shows the north-south transect where samples were collected 
sources of pollution and significantly helped reduce the amount of runoff reaching nearby waterbodies [28, 29]. However, it did not affect pre-existing contaminants from past human effluents and emissions that for the most part remain trapped in the sediments of estuaries all over the world. What happens after important sources of contaminants are eliminated? Overtime, do legacy levels of contaminants in surface sediments remain the same, decrease, or do they continue to increase? If they increase, does this reflect new sources, or is it the result of the remobilization of a preexisting pool within the sediment profile? This long-term study is meant to help understand possible contaminant pathways overtime. We measure changes in metal concentration after the Clean Water Act where presumably, most outside sources have been controlled or eliminated. In 2006, a degraded 17.4 ha marshland was selected for restoration and the entire sediment profile, about $50 \mathrm{~cm}$ deep, was removed and replaced and with "clean engineered sediment." This restoration created a unique opportunity for a long-term study of metal pathways in impaired marshlands. The objective of this study is to determine whether metals continue to accumulate in the absence of new sources, measure the effect on metal mobility by adding compost to the "clean engineered sediment", and finally, as a result of metal cycling within the sediment profile, measure the changes of the surface sediment concentration overtime.

\section{Methods and materials}

\subsection{Study area}

The study area is located in New Jersey (USA) along the Hackensack River and by the Town of Secaucus $\left(40^{\circ} 47^{\prime}\right.$ $22.36^{\prime \prime} \mathrm{N} ; 74^{\circ} 03^{\prime} 23.51^{\prime \prime} \mathrm{W}$ ) (Fig. 1). In 2006, the first $50 \mathrm{~cm}$ of the sediment profile and associated vegetation and rhizomes (Phragmites australis) were removed from a 17.4 ha site and replaced with a combination of offshore dredge sand and compost. The compost was mainly freshwater pond dredge and leaves. We refer to this as "clean engineered sediment." Most of the site was graded to $60 \mathrm{~cm}$ a.s.l. (NAVD88) to accommodate a low marsh plant community. Two smaller areas divided into north and south (total of $3.2 \mathrm{ha}$ ) were graded to $\sim 1 \mathrm{~m}$ a.s.l. The north side was capped with $50 \mathrm{~cm}$ of sand and the south side with $50 \mathrm{~cm}$ of a 1:5 mixture of compost to sand (Fig. 2). These two areas were planted with high marsh species: Spartina patens (salt meadow hay), Distichlis spicata (saltgrass), Spartina cynosuroides (big cordgrass), and Juncus gerardii (salt meadow rush). The low marsh area ( 14 ha) was planted with Spartina alterniflora. The tidal exchange was restored in 2007 after regrading and planting were completed.

\subsection{Sampling method}

Sampling points were located along a $200 \mathrm{~m}$ transect perpendicular to a tidal creek separating north and south high marsh areas. Samples were collected at elevations: $1.1 \mathrm{~m}$, $0.9 \mathrm{~m}$, and $0.6 \mathrm{~m}$ (NAVD88) to coincide with the spring high water level (MHWS, high marsh), mean high water level (MHW), and mean tide level (MTL low marsh), respectively. Three replicate samples from surface sediments and depths greater than $25 \mathrm{~cm}$ were collected for all sampling points with a soil auger and Russian peat corer that were cleaned with deionized water between samples. Deep samples at elevation mean tide level $(0.6 \mathrm{~m})$ and close to the creek have a thinner cap, and legacy sediments are closer to the surface (Fig. 2).

The first sampling took place October of 2007 and represents the starting condition before the tidal flow was restored and reached the engineered sediments. Subsequent samplings occurred once per year during April-June. A total of 36 sediment samples were collected every year from 2007 to 2016 and 2018. Samples were kept in labeled plastic bags in a cooler and transported to the laboratory for grain size and chemical analysis. No samples were collected in 2017, and additional samples were collected in 2013 immediately after Hurricane Sandy. Water
Fig. 2 Transect profile showing the north and south treatment areas and sampling point locations at mean tide level (MTL), mean high water (MHW), and mean high water spring (MHWS)
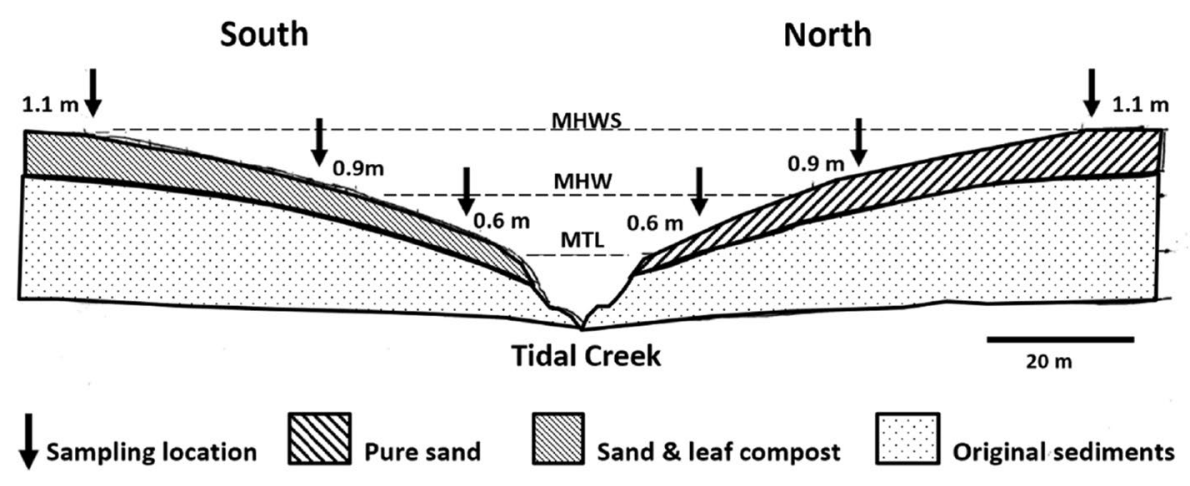

SN Applied Sciences A SPRINGER NATURE journal 
samples for metal analysis were grabbed samples using acid-washed and pre-labeled plastic bottles. The same instruments, analysis methods, and procedures were used consistently throughout this 11-year study.

\subsection{Chemical analysis}

A YSI Model 6820 multi-parameter probe was used to measure turbidity, conductivity, dissolved oxygen (DO), $\mathrm{pH}$, salinity, and temperature from the water column in the main stem of the Hackensack River in proximity to the site. Before each sampling event, the $\mathrm{pH}$ sensor was calibrated using a 3-point calibration (4.0, 7.0, and 10.0); the conductivity sensor was calibrated using $10 \mu \mathrm{S} / \mathrm{cm}$ and $1.1 \mu \mathrm{S} / \mathrm{cm}$ standards, and the dissolved oxygen sensor was calibrated using $100 \%$ oxygen and a $0 \%$ standard.

The percentage of moisture of sediment samples was measured by Standard Method D 2974. For the sediment samples with the percentage of moisture higher than $20 \%$, we used EPA Method $9040 \mathrm{C}$ to measure $\mathrm{pH}$, and for the sediment samples with less than $20 \%$ of moisture, we used EPA Method $9045 \mathrm{C}$ to measure the $\mathrm{pH}$ value. The percentage of organic matter was determined using weight loss on ignition (LOI) method [30]. Metals from sediment samples were digested using EPA Method 3051A [31]. In a microwave digestion vessel (Bucks Scientific, BMS1), $0.2 \mathrm{~g}$ of sediment sample was digested with $7 \mathrm{~mL}$ of ultrapure nitric acid $\left(\mathrm{HNO}_{3}, 67-70 \%, \mathrm{w} / \mathrm{w}, \mathrm{EMD}\right)$. Standard reference material 1944 (New York/New Jersey Waterway Sediment, NIST) was digested with samples for quality control. After digestion, the samples were diluted to $50 \mathrm{~mL}$ with ultrapure water and stored in polypropylene centrifuge tubes at $4{ }^{\circ} \mathrm{C}$ for further analysis. Water sample digestion was performed using the Hotblock (Environmental Express) procedure (EPA Method 1638). For dissolved metal analysis, the $100 \mathrm{~mL}$ of water sample was filtered with a $0.45 \mu \mathrm{m}$ Whatman filter and then acidified with nitric acid. For total recoverable metals, water samples were acidified and digested in the container directly. Final solutions were analyzed using graphite furnace atomic absorption spectrometry (GF-AAS). Cadmium, chromium, copper, iron, manganese, nickel, lead, and zinc were analyzed using the flame atomic absorption spectrometry, and mercury was analyzed using the cold vapor method. Dissolved metals were only measured after 2011.

\subsection{Statistical analysis}

Parametric and nonparametric tests were used to determine differences between surface and sub-surface sediments, terrain elevations, and compost treatment. Specifically, we used two-sample $t$ tests, the analysis of variance (ANOVA) $\mathrm{F}$ tests (equal and unequal variances), and the
Wilcoxon and Kruskal nonparametric test. Multi-variable linear regression analysis was used to explore the relationship between metal concentration and precipitation amounts. The confidence interval for all tests was set to $p<0.05$.

\section{Results and discussion}

\subsection{Site and water column conditions}

The estuary is a mesohaline environment with close to neutral $\mathrm{pH}$ and $50 \%$ oxygen saturation (Table 1). The average tidal amplitude ranges from 1.2 to $1.8 \mathrm{~m}$. Analysis of sediment fluxes based on 2 years of near-continuous monitoring indicates that approximately 14 percent of suspended solids carried into marshlands from the Hackensack River and tidal creeks are trapped by the marsh surface [32]. Sediment measurements above a feldspar marker between 2008 and 2019 revealed the average vertical accretion rate is $\sim 5.5 \mathrm{~mm} /$ year. In the water column, $\mathrm{Cd}$, $\mathrm{Cr}, \mathrm{Cu}, \mathrm{Pb}$, and $\mathrm{Fe}$ are largely bound to suspended material ( $<50 \%$ dissolved), and $\mathrm{Mn}, \mathrm{Ni}$, and $\mathrm{Zn}$ exist predominantly in the dissolved fraction ( $>50 \%$ dissolved) (Table 2 ). Our metal concentrations are comparable to what is found in Shanghai estuary [10], estuaries in Spain [13], and the

Table 1 Water quality parameters averages, standard deviations, minimum and maximum values (2007-2018). Hackensack River next to the study site

\begin{tabular}{lccll}
\hline & $N$ & Average & Max. value & Min. value \\
\hline Turbidity (NTU) & 94 & $20.0 \pm 10.4$ & 54.3 & 4.9 \\
Temperature $\left({ }^{\circ} \mathrm{C}\right)$ & 96 & $15.2 \pm 8.6$ & 28.6 & 0.8 \\
Conductivity $(\mathrm{mS} / \mathrm{cm})$ & 94 & $8.3 \pm 4.3$ & 22.8 & 0.6 \\
Salinity (ppt) & 94 & $4.7 \pm 2.6$ & 13.7 & 0.3 \\
$\mathrm{pH}$ & 96 & $7.6 \pm 0.3$ & 8.4 & 6.9 \\
$\mathrm{DO}(\mathrm{mg} / \mathrm{L})$ & 96 & $7.2 \pm 2.6$ & 14.8 & 2.7 \\
\hline
\end{tabular}

Table 2 Average total and dissolved metals from the water column. (2012-2018, N=56). Hackensack River next to the study site

\begin{tabular}{lccl}
\hline & Total, $\mu \mathrm{g} / \mathrm{L}$ & Dissolved, $\mu \mathrm{g} / \mathrm{L}$ & $\%$ Dissolved \\
\hline $\mathrm{Cd}$ & $0.157 \pm 0.224$ & $0.0736 \pm 0.0706$ & 47 \\
$\mathrm{Cr}$ & $7.35 \pm 4.78$ & $2.76 \pm 3.16$ & 38 \\
$\mathrm{Cu}$ & $8.77 \pm 10.1$ & $4.26 \pm 7.48$ & 49 \\
$\mathrm{Fe}$ & $1035 \pm 696$ & $105 \pm 61.4$ & 10 \\
$\mathrm{Mn}$ & $264 \pm 87.8$ & $208 \pm 74.4$ & 79 \\
$\mathrm{Ni}$ & $4.52 \pm 2.84$ & $3.28 \pm 2.15$ & 72 \\
$\mathrm{~Pb}$ & $4.55 \pm 2.50$ & $1.08 \pm 1.24$ & 24 \\
$\mathrm{Zn}$ & $22.8 \pm 10.2$ & $13.5 \pm 8.29$ & 59 \\
\hline
\end{tabular}


Netherlands [33]. Our site has greater enrichment of $\mathrm{Hg}$, $\mathrm{Pb}$, and zinc compared to the Thames river estuary [12] and slightly lower concentrations of $\mathrm{Pb}$ and zinc compared to the Ganges estuary in India [11]. Overall, Meadowlands metal concentrations in the water column and sediments are similar or higher than values found in similar estuaries worldwide.

\subsection{Sediments profile conditions}

The sediment profile has $\sim 50 \mathrm{~cm}$ of engineered sediments overlaying the original sediments. The percent of fine grains (clay + silts) averaged about $10 \%$ for

Table 3 Average $\mathrm{pH}$ and \% organic matter of surface and deep sediment over time

\begin{tabular}{lllll}
\hline & pH surface & pH depth & \% OM surface & \% OM depth \\
\hline 2007 & $6.41 \pm 1.09$ & $5.99 \pm 1.19$ & $7.14 \pm 8.39$ & $14.61 \pm 7.68$ \\
2008 & $6.68 \pm 0.52$ & $6.53 \pm 0.56$ & $8.94 \pm 9.57$ & $19.16 \pm 9.20$ \\
2009 & $6.04 \pm 0.38$ & $5.78 \pm 0.65$ & $9.50 \pm 10.88$ & $16.23 \pm 12.96$ \\
2010 & $7.62 \pm 0.23$ & $7.37 \pm 0.34$ & $9.97 \pm 11.81$ & $13.94 \pm 7.19$ \\
2011 & $7.62 \pm 0.34$ & $7.38 \pm 0.39$ & $9.97 \pm 1.93$ & $13.94 \pm 0.81$ \\
2012 & $7.62 \pm 0.23$ & $7.37 \pm 0.34$ & $9.97 \pm 11.81$ & $13.94 \pm 7.19$ \\
2013 & $7.24 \pm 0.47$ & $7.29 \pm 0.41$ & $5.94 \pm 5.91$ & $16.35 \pm 12.48$ \\
2014 & $6.87 \pm 0.55$ & $7.01 \pm 0.20$ & $7.88 \pm 5.83$ & $12.18 \pm 5.33$ \\
2015 & $6.75 \pm 0.65$ & $6.85 \pm 0.29$ & $8.01 \pm 6.09$ & $13.77 \pm 5.23$ \\
2016 & $6.81 \pm 0.37$ & $6.81 \pm 0.27$ & $5.94 \pm 4.55$ & $13.39 \pm 9.30$ \\
2018 & $6.50 \pm 0.53$ & $6.55 \pm 0.50$ & $4.98 \pm 4.47$ & $10.76 \pm 5.02$ \\
\hline
\end{tabular}

Measurements represent the average of the surface and deep samples $(N=18)$ surface sediments $(<25 \mathrm{~cm})$ and $23 \%$ for deep sediments $(>25 \mathrm{~cm})$. Higher silts and clay content from deep samples explains the higher concentration of metals deeper in the sediments [33]. As expected, moisture is always greater lower in the profile $(>25 \mathrm{~cm})$. The $\mathrm{pH}$ was consistently lower in deep sediments compared to surface samples and reflects the effect of seawater frequently reaching surface sediments from tidal inundation [34]. The percent organic matter (OM) was consistently higher ( 6\%) in the deeper sediments. Overtime, there was a significant decrease, i.e., a net export, in organic matter from the sediment profile to the estuary (Table 3). As plant communities continue to develop and reach a steady-state, the net export rate should be a fraction of the primary productivity. This pattern is in agreement with Teal (1996) who predicted that marshlands are effective pumps of detritus and dissolved organic matter into the estuary and as such, play a critical role in supporting the primary consumer community [35].

\subsection{Metal concentrations by sediment depth}

Except for $\mathrm{Hg}$, all metals had significantly higher concentrations at depths $>25 \mathrm{~cm}$ where the silt and clay fractions are twice that of surface sediments. For $\mathrm{Ni}$ and $\mathrm{Zn}$, which exist mainly in the dissolved phase, concentrations at depth where there is more moisture are almost doubled compared to surface concentrations (Table 4). Lead, which occurs mainly as a precipitated sulfide mineral, also had concentrations at depth that was twice as high compared to the surface. Most metals (i.e., $\mathrm{Cd}, \mathrm{Cr}, \mathrm{Cu}, \mathrm{Fe}$, and $\mathrm{Mn}$ ) showed $\sim 20 \%$ higher concentrations deeper in the profile. The exception was $\mathrm{Hg}$. No significant differences in

Table 4 Mean metal concentration $(\mathrm{mg} / \mathrm{kg}$ ) by pre-restoration, depth, capping type, and marsh surface elevation

\begin{tabular}{|c|c|c|c|c|c|c|c|c|c|}
\hline $\mathrm{mg} / \mathrm{kg}$ & $\mathrm{Cd}$ & $\mathrm{Cr}$ & $\mathrm{Cu}$ & $\mathrm{Fe}$ & $\mathrm{Hg}$ & $\mathrm{Mn}$ & $\mathrm{Ni}$ & $\mathrm{Pb}$ & $\mathrm{Zn}$ \\
\hline Pre-restoration & 1.74 & 475 & 145 & & 7.88 & & 101 & 225 & 356 \\
\hline \multicolumn{10}{|l|}{ Surface/depth, $N=72$} \\
\hline Surface & $1.95 \pm 1.54$ & $146 \pm 200$ & $67.7 \pm 80.5$ & $16,218 \pm 11,387$ & $3.14 \pm 3.72$ & $423 \pm 594$ & $29.5 \pm 27.1$ & $97.2 \pm 79.8$ & $131 \pm 119$ \\
\hline Depth & $2.83 \pm 1.8$ & $171 \pm 220$ & $86.1 \pm 51$ & $20,279 \pm 8958$ & $3.57 \pm 3.74$ & $644 \pm 963$ & $51.1 \pm 34.5$ & $183 \pm 67.3$ & $242 \pm 111$ \\
\hline$p$ value ( $t$ test) & $<0.001$ & 0.001 & $<0.001$ & $<0.001$ & 0.06 & $<0.001$ & $<0.001$ & $<0.001$ & $<0.001$ \\
\hline \multicolumn{10}{|c|}{ Capping type, No compost (north)/compost (south), $N=72$} \\
\hline No compost (north) & $2.44 \pm 1.73$ & $185 \pm 264$ & $85.9 \pm 85.1$ & $18,666 \pm 10,977$ & $4.02 \pm 4.29$ & $680 \pm 1087$ & $42.4 \pm 36.1$ & $149 \pm 92.7$ & $198 \pm 149$ \\
\hline Compost (south) & $2.34 \pm 1.85$ & $132 \pm 177$ & $67.9 \pm 52.7$ & $17,830 \pm 11,091$ & $2.69 \pm 3.58$ & $387 \pm 516$ & $38.1 \pm 33.9$ & $131 \pm 86.6$ & $176 \pm 119$ \\
\hline$p$ value ( $t$ test) & 0.94 & 0.92 & 0.28 & 0.91 & 0.15 & 0.59 & 0.84 & 0.78 & 0.38 \\
\hline \multicolumn{10}{|c|}{ Marsh surface elevation, $N=48$} \\
\hline $1.1 \mathrm{~m}$ & $1.7 \pm 1.25$ & $23.8 \pm 17.4$ & $49.4 \pm 75.2$ & $11,436 \pm 6181$ & $1.14 \pm 1.44$ & $135 \pm 84$ & $15.7 \pm 8.58$ & $107 \pm 79$ & $114 \pm 86.1$ \\
\hline $0.9 \mathrm{~m}$ & $1.88 \pm 1.34$ & $64.6 \pm 71.7$ & $57.3 \pm 54.3$ & $14,530 \pm 9118$ & $1.85 \pm 1.85$ & $697 \pm 1270$ & $29.8 \pm 27$ & $127 \pm 99.6$ & $144 \pm 102$ \\
\hline $0.6 \mathrm{~m}$ & $3.59 \pm 2.02$ & $387 \pm 261$ & $125 \pm 56.7$ & $28,907 \pm 8209$ & $7.08 \pm 4.63$ & $772 \pm 621$ & $75.5 \pm 30.1$ & $187 \pm 68$ & $303 \pm 125$ \\
\hline$p$ value (Anova-equal) & $<0.001$ & $<0.001$ & $<0.001$ & $<0.001$ & $<0.001$ & $<0.001$ & $<0.001$ & $<0.001$ & $<0.001$ \\
\hline ERM $^{\mathrm{a}}$ & 9.6 & 370 & 270 & & 0.71 & & 52 & 218 & 410 \\
\hline
\end{tabular}

${ }^{\mathrm{a} E R M: ~ E f f e c t s ~ r a n g e ~ m e d i u m ~[40] ~}$ 
$\mathrm{Hg}$ concentration were observed between the surface and deep sediments $(3.14 \pm 3.72 \mathrm{mg} / \mathrm{kg}$ and $3.57 \pm 3.74 \mathrm{mg} / \mathrm{kg}$, respectively). The average $\mathrm{Hg}$ levels exceeded the effects range medium criteria (ERM) [34] everywhere in the sediment profile and at different marsh elevations. As a result, the average $\mathrm{Hg}$ concentration in our study area exceeded all other comparable estuaries investigated.

The percent change $\left(C / C_{0}\right)$ of the average metal concentration in surface and depth sediment over time is showed in Fig. 3. Throughout the study period, the percent changes of most metals fluctuated around $100 \%$ in the surface sediment. However, there are peaks in 2012, 2015, and 2018 which are the very wet years. In 2010 and 2016 (drought years), the percent changes of most metals decreased. In the depth sediment samples, most metal concentrations, except $\mathrm{Cd}$, have less variation compared to surface sediment samples. Metal concentration in deep sediment decreased from 2007 to 2010 and increased gradually from 2010 to 2018 . The variation of percent change increased from 2015 to 2018 and probably related to extreme weather events (drought years and wet years).

\subsection{Metal concentrations by compost treatment}

Metals had lower concentrations in the south side where the compost amendment was added; however, these differences were not statistically significant $(p<0.05)$. The organic matter with its large surface area and sizeable cation exchange capacity should promote the mobility of metals through organic ligands even in the presence of sulfides $[6,18]$. The sediments at the study site have Sulfihemists kind of conditions and contain high levels of
Fig. 3 Percent change $\left(C / C_{0}\right)$ of the average metal concentration in surface sediments $(<25 \mathrm{~cm})$ and depth $(>25 \mathrm{~cm})$ throughout the 2007 to 2018 study period. *Drought years, 2010 and $2016 .{ }^{* *}$ Very wet year, 2012, 2015, and 2018
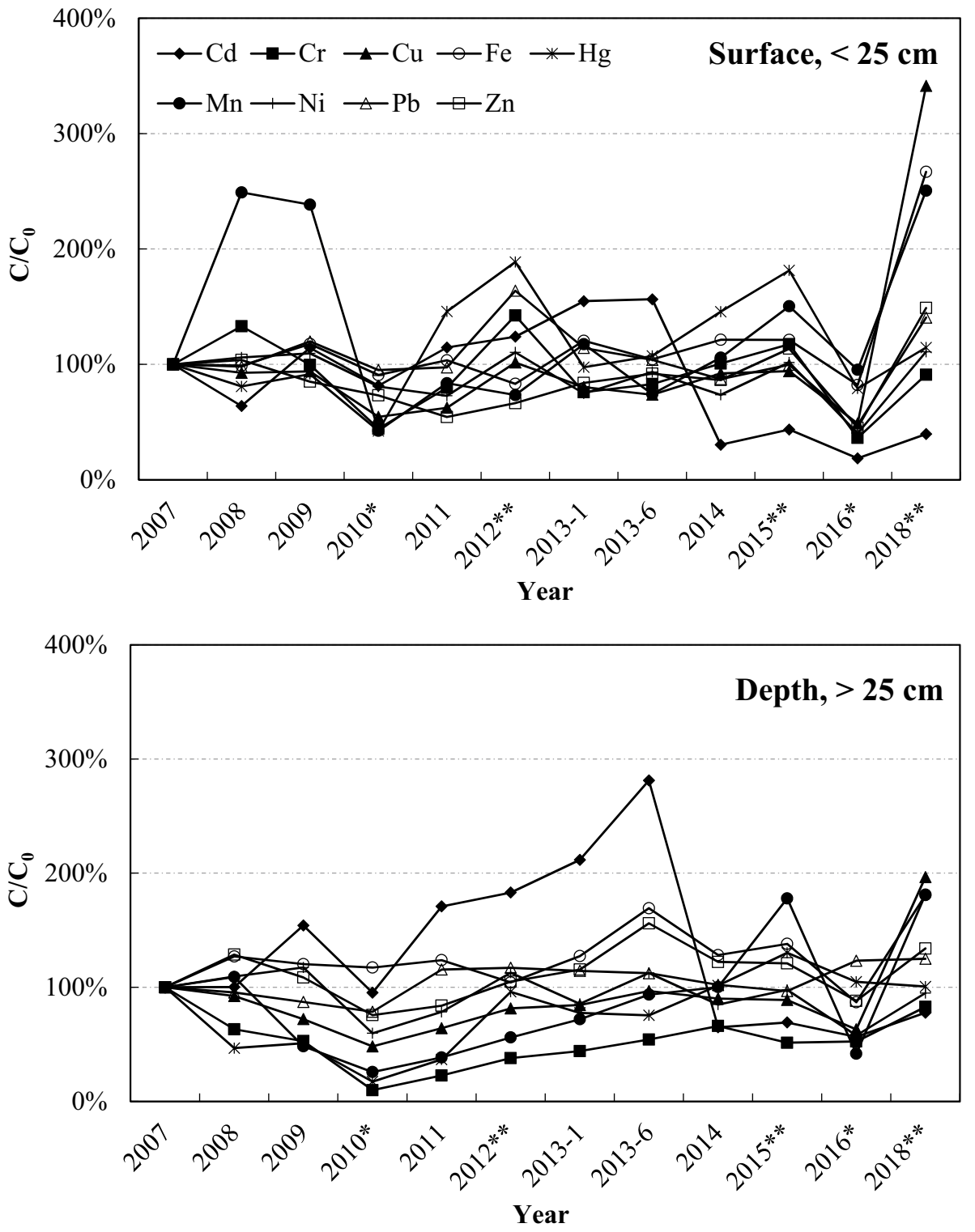
naturally occurring organic matter [36]. The effects of the added compost if any were hidden by the high quantities of naturally occurring organic matter already present. According to our results, we cannot conclude that the added organic matter (1:5 compost to sand) had any effect on the concentration of metals (Table 4).

\subsection{Metal concentrations by terrain elevation}

The marsh surface was sampled along a transect covering a range of elevations from $1.1 \mathrm{~m}$ to $0.6 \mathrm{~m}$ a.s.l., and where the north and south segments of the transect sloped toward a tidal creek (Fig. 2). We found a highly significant $(p<0.001)$ and a negative relationship between marsh surface elevation and metal concentration. For example, the average $\mathrm{Cr}$ concentration for surface and deep samples, at elevation $0.6 \mathrm{~m}$ (near the creek), is $\sim 3$ times higher than that at elevation $0.9 \mathrm{~m}$, and 16 times higher than at elevation $1.1 \mathrm{~m}$ (Table 4). The thicknesses of the added cap taper off as it reaches the creek at elevation $0.6 \mathrm{~m}$. Samples collected at these lower elevations captured mostly metals from the legacy sediment profile (Fig. 2). Mercury showed lower concentrations at higher terrain elevations and away from the creek $(1.14 \pm 1.44 \mathrm{mg} / \mathrm{kg}$ at $1.1 \mathrm{~m}$; $1.85 \pm 1.85 \mathrm{mg} / \mathrm{kg}$ at $0.9 \mathrm{~m})$ and much higher concentration $(7.08 \pm 4.63 \mathrm{mg} / \mathrm{kg})$ at the elevation of $0.6 \mathrm{~m}$, where most of the sediments are not from the engineered cap but from the original sediment profile that remains under anoxic conditions most of the time (Table 4).

Figure 4 shows the percent change in metal concentration at different elevations after the engineered sediments were exposed to the tides in 2007. At lower elevations $(0.6 \mathrm{~m})$, the percent change $\left(C / C_{0}\right)$ shows that overtime, metal concentrations decreased compared to the initial 2007 levels. Only $\mathrm{Cu}, \mathrm{Mn}$, and Fe end up slightly higher than the initial conditions after 11 years of exposure to the tide. The variations in metal concentration at elevation $0.9 \mathrm{~m}$ are larger compared to elevation $0.6 \mathrm{~m}$. Compared to 2007 levels, and by the end of the study period, at elevation $0.9 \mathrm{~m}$ there is an increase in the concentration of all metals. At 1.1 m elevation, the percent change over time is small. The exception is the last 3 years where a significant increase in the concentration of all metals coincided with a very dry year (2016) followed by a very wet year (2018). At all three elevations, $\mathrm{Cd}$ and $\mathrm{Hg}$ showed the greatest variability over time. These two trace metals were present in the smallest quantities compared to all other metals (Table 4). The greatest variability in metal concentration over time is from the intermediate $0.9 \mathrm{~m}$ elevation. At this elevation, alternating oxic and anoxic conditions is consistent compared to elevation $0.6 \mathrm{~m}$ where anoxic conditions prevail, and elevation $1.1 \mathrm{~m}$ where oxic conditions tend to prevail.

\subsection{Metal concentrations over time}

The variation in metal concentration over time (average of the surface and deep) is showed in relation to the initial 2007 conditions in Fig. 5. All metals except for Fe dropped in concentrations during the drought years of 2010 and 2016. On the other hand, metal concentration in the sediments increased relative to 2007 during 2012 and 2018 which were among the top 5 wettest years in New Jersey since 1895 . There is a clear pattern of increasing metals in sediments when dry years are followed by wet years (Fig. 5). During wet years, there is greater complexation of metals with dissolved organic matter in pore water which increases their mobility along the sediment profile. The most likely mechanism for the movement of metals up and down the sediment profile is metal complexation with organic matter and tidally influenced oxidation of metal sulfides [37]. We also observed that trace metals closely follow the ups and downs of Fe and Mn. This confirms that Fe oxides and $\mathrm{Mn}$ oxides along with organic ligands play an important role in the movement of trace metals. Close to $53 \%$ of the variation in Fe concentration can be explained by $\mathrm{Mn}$ levels in the sediment. Similarly, approximately $50 \%$ of the variation in the concentrations of $\mathrm{Cr}$, $\mathrm{Cu}$, and $\mathrm{Zn}$ can be explained by the variations in Fe and/or $\mathrm{Mn}$ (Table 5). Under anoxic conditions, Fe oxides and Mn oxides containing Fe(III) and $\mathrm{Mn}$ (IV) are used by microbes as terminal electron acceptors in respiration which leads to reductive dissolution where $\mathrm{Fe}(\mathrm{II})$ and $\mathrm{Mn}$ (II) are released into the pore water solution along with their associated trace metal sorbates.

The yearly averages for $\mathrm{Cr}, \mathrm{Cd}$, and Ni show no significant trends of accumulation as their slopes over time are not significantly different from zero $(p>0.05)$. On the other hand, $\mathrm{Pb}, \mathrm{Zn}, \mathrm{Mn}, \mathrm{Fe}$, and $\mathrm{Cu}$ show slight positive slopes over time. No net increase or accumulation in trace metals over time is observed when spikes from dry to wet year are removed from the analysis. Removing spike years (e.g., 2018 data not included) eliminates the effects of remobilization due to weather. We suspect that the formation of soluble organic ligands, reductive dissolution, and oxidation of metal sulfides are the main mechanisms by which the same pool of metals moves up and down the sediment profile. Contrary to all the other metals, $\mathrm{Hg}$ did not spike during wet years and showed a significant positive slope $(p<0.001)$ throughout the study period. The main pathway for $\mathrm{Hg}$ is atmospheric deposition [38, 39]. Similarly, cadmium showed an enrichment trend over time regardless of the year, and $40 \%$ of $\mathrm{Cd}$ variation is explained by the amount of rain. We conclude that $\mathrm{Hg}$ and $\mathrm{Cd}$ enrichment patterns can be explained by active contributions from outside sources in the form of wet and dry atmospheric deposition. 
Fig. 4 Percent change $\left(C / C_{0}\right)$ of the average metal concentration at different marsh surface elevations $(0.6 \mathrm{~m}, 0.9 \mathrm{~m}$, and $1.1 \mathrm{~m}$ ) throughout the 2007 to 2018 study period. ${ }^{*}$ Drought years, 2010 and 2016. ${ }^{* *}$ Very wet year, 2012, 2015, and 2018
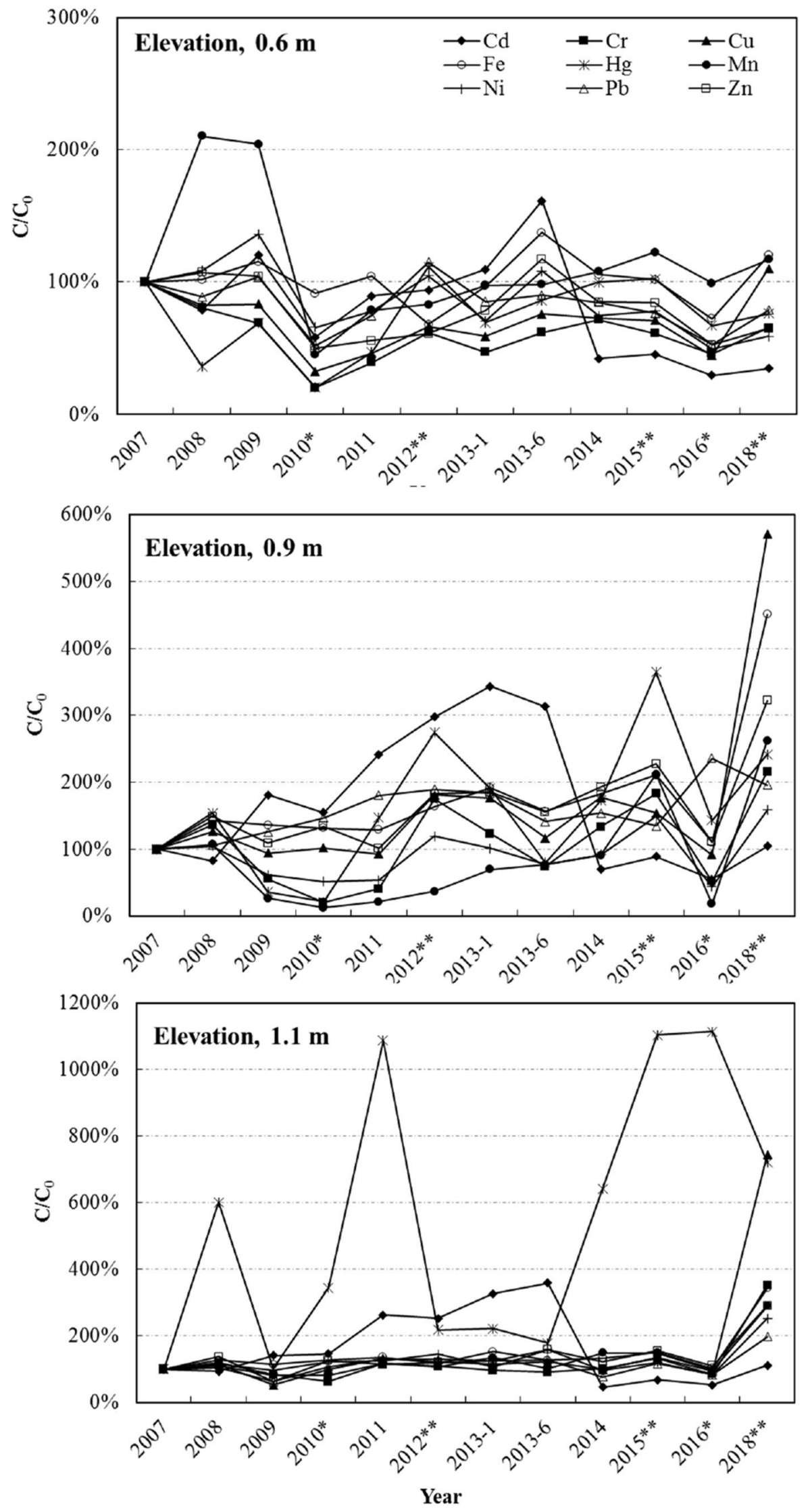
Fig. 5 Percent change $\left(C / C_{0}\right)$ of the average sediment metal concentration in relation to 2007 when the site was opened to the tide. *Drought years, 2010 and 2016 . $^{* *}$ Very wet year, 2012, 2015, and 2018

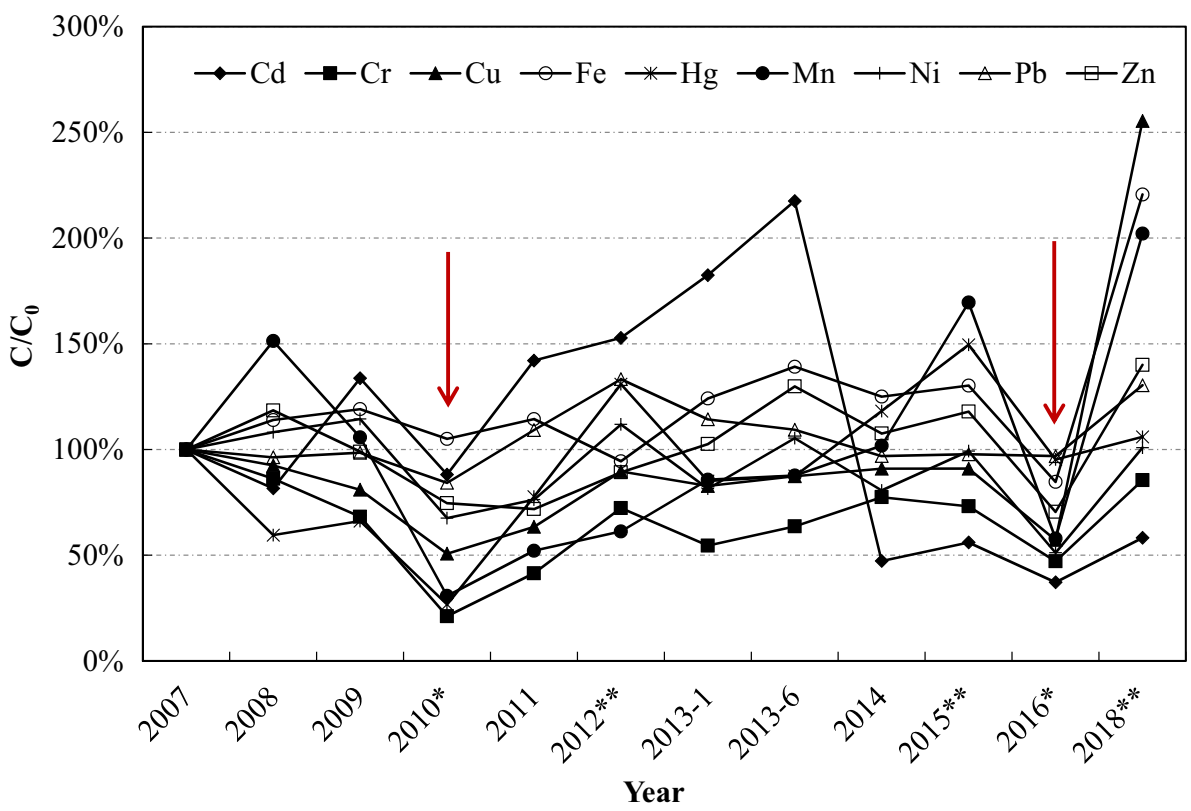

\begin{tabular}{llllllllll}
\hline & $\mathrm{Cd}$ & $\mathrm{Cr}$ & $\mathrm{Cu}$ & $\mathrm{Fe}$ & $\mathrm{Hg}$ & $\mathrm{Mn}$ & $\mathrm{Ni}$ & $\mathrm{Pb}$ & $\mathrm{Zn}$ \\
\hline $\mathrm{Mn}$ & 0.13 & $\mathbf{0 . 4 9}$ & $\mathbf{0 . 5 8}$ & $\mathbf{0 . 5 3}$ & 0.16 & & 0.27 & 0.05 & $\mathbf{0 . 7 1}$ \\
$\mathrm{Fe}$ & 0.01 & 0.09 & $\mathbf{0 . 8 2}$ & & 0.03 & $\mathbf{0 . 5 3}$ & 0.09 & 0.21 & $\mathbf{0 . 5 8}$
\end{tabular}

Coefficients of determination with a moderate effect $\left(R^{2}>0.49\right)$ are shown in bold indicating that $49 \%$ or more of the variation in the concentrations of $\mathrm{Cr}, \mathrm{Cu}$, and $\mathrm{Zn}$ can be explained by the variations in $\mathrm{Mn}$ and $\mathrm{Fe}$
Table 5 Coefficients of determination $\left(R^{2}\right)$ between metal concentrations that over time, the same pool of metals moves up the sediment profile during wet years and down during dry years. The mechanisms facilitating this mobility are the formation of organic ligands, reductive dissolution of $\mathrm{Fe}$ and $\mathrm{Mn}$ oxides, and the oxidation of metal sulfides. The exceptions were mercury and cadmium that showed a clear and steady enrichment pattern by entering the system through a combination of wet and dry atmospheric deposition. These findings show that over decadal periods, the main driver mobilizing metals through the sediment profile are dry periods followed by wet periods. This study demonstrates that an increasing frequency and duration of dry periods along with increased frequency and severity of storms from changing global weather patterns have the potential to create conditions for greater bioavailability of legacy metals from this and similar estuaries worldwide.

Acknowledgements This study was supported by the Meadowlands Environmental Research Institute and the New Jersey Sports and Exposition Authority. The authors thank the MERI Geographical Information System group for making the maps. Inputs from Michael Stepowyj, Ildiko Pechmann, Adriana Messyasz, and Sandy Speers are also appreciated. 
Author contributions FJA designed and supervised this study and wrote the manuscript. YY conducted field sampling and sample analysis and wrote the manuscript. JG conducted the field sampling and sample analysis and contributed to the final version of the manuscript. YL performed most of the sample analysis in this study and contributed to the final version of the manuscript.

Funding This study was supported by the Meadowlands Environmental Research Institute and the New Jersey Sports and Exposition Authority (NJSEA).

Availability of data and material The full data set of this study is included in the supplementary material.

\section{Compliance with ethical standards}

Conflict of interest The authors declare that they have no conflict of interest.

\section{References}

1. Costanza R, d'Arge R, de Groot R, Farber S, Grasso M, Hannon B, Limburg K, Naeem S, O'Neill RV, Paruelo J, Raskin RG, Sutton P, van den Belt M (1997) The value of the world's ecosystem services and natural capital. Nature 387(6630):253-260. https://doi. org/10.1038/387253a0

2. Esteves LS (2013) Is managed realignment a sustainable long-term coastal management approach? J Coast Res 65(10065):933-938. https://doi.org/10.2112/si65-158.1

3. Teuchies J, Singh G, Bervoets L, Meire P (2013) Land use changes and metal mobility: multi-approach study on tidal marsh restoration in a contaminated estuary. Sci Total Environ. https://doi. org/10.1016/j.scitotenv.2013.01.053

4. Simpson SL, Pryor ID, Mewburn BR, Batley GE, Jolley D (2002) Considerations for capping metal-contaminated sediments in dynamic estuarine environments. Environ Sci Technol 36(17):3772-3778. https://doi.org/10.1021/es025632v

5. Tatone LM, Bilos C, Skorupka CN, Colombo JC (2009) Vertical fluxes and accumulation of trace metals in superficial sediments of the Río de la Plata estuary, Argentina. Bull Environ Contam Toxicol 83(6):913-919. https://doi.org/10.1007/s0012 8-009-9878-2

6. ElBishlawi H, Shin JY, Jaffe PR (2013) Trace metal dynamics in the sediments of a constructed and natural urban tidal marsh: the role of iron, sulfide, and organic complexation. Ecol Eng 58:133-141. https://doi.org/10.1016/j.ecoleng.2013.06.018

7. Weis P, Barrett KR, Proctor T, Bopp RF (2005) Studies of a contaminated brackish marsh in the Hackensack Meadowlands of northeastern New Jersey: an assessment of natural recovery. Mar Pollut Bull 50(11):1405-1415. https://doi.org/10.1016/j. marpolbul.2005.06.013

8. Morse JW, Luther GW (1999) Chemical influences on trace metal-sulfide interactions in anoxic sediments. Geochim Cosmochim Acta 63(19):3373-3378. https://doi.org/10.1016/S0016 -7037(99)00258-6

9. Zwolsman JJG, van Eck GTM (1999) Geochemistry of major elements and trace metals in suspended matter of the Scheldt estuary, southwest Netherlands. Mar Chem 66(1):91-111. https ://doi.org/10.1016/S0304-4203(99)00026-2

10. Han D, Cheng J, Hu X, Jiang Z, Mo L, Xu H, Ma Y, Chen X, Wang H (2017) Spatial distribution, risk assessment and source identification of heavy metals in sediments of the Yangtze River Estuary,
China. Mar Pollut Bull 115(1):141-148. https://doi.org/10.1016/j. marpolbul.2016.11.062

11. Samanta S, Dalai TK (2018) Massive production of heavy metals in the Ganga (Hooghly) River estuary, India: global importance of solute-particle interaction and enhanced metal fluxes to the oceans. Geochim Cosmochim Acta 228:243-258. https://doi. org/10.1016/j.gca.2018.03.002

12. Pope N, Langston W (2011) Sources, distribution and temporal variability of trace metals in the Thames Estuary. Hydrobiologia 672:49-68. https://doi.org/10.1007/s10750-011-0758-5

13. Morillo J, Usero J (2008) Trace metal bioavailability in the waters of two different habitats in Spain: huelva estuary and Algeciras Bay. Ecotoxicol Environ Saf 71:851-859. https://doi. org/10.1016/j.ecoenv.2008.01.016

14. Huerta-Diaz MA, Delgadillo-Hinojosa F, Hernández-Ayón $M$, Segovia-Zavala JA, García-Esquivel Z, López-Zárate H, Siqueiros-Valencia A, Galindo-Bect $S$ (2008) Diagnosis of trace metal contamination in sediments: the example of Ensenada and $\mathrm{EI}$ Sauzal, two harbors in Baja California, Mexico. Mar Environ Res 66(3):345-358. https://doi.org/10.1016/j.marenvres.2008.05.008

15. Zhang C, Wang L, Li G, Dong S, Yang J, Wang X (2002) Grain size effect on multi-element concentrations in sediments from the intertidal flats of Bohai Bay, China. Appl Geochem 17(1):59-68. https://doi.org/10.1016/S0883-2927(01)00079-8

16. Nayar S, Miller DJ, Hunt A, Goh BPL, Chou LM (2007) Environmental effects of dredging on sediment nutrients, carbon and granulometry in a tropical estuary. Environ Monit Assess 127(1):1-13. https://doi.org/10.1007/s10661-006-9253-2

17. Singh KT, Nayak GN (2009) sedimentary and geochemical signatures of depositional environment of sediments in mudflats from a Microtidal Kalinadi Estuary, Central West Coast of India. J Coast Res 610(253):641-650

18. Weng L, Temminghoff EJM, Lofts S, Tipping E, Van Riemsdijk WH (2002) Complexation with dissolved organic matter and solubility control of heavy metals in a sandy soil. Environ Sci Technol 36(22):4804-4810. https://doi.org/10.1021/es0200084

19. Wen $Y$, Yang $Z$, Xia X (2013) Dissolved and particulate zinc and nickel in the Yangtze River (China): distribution, sources and fluxes. Appl Geochem 31:199-208. https://doi.org/10.1016/j. apgeochem.2013.01.004

20. Martino M, Turner A, Nimmo M (2004) Distribution, speciation and particle-water interactions of nickel in the Mersey Estuary, UK. Mar Chem 88:161-177. https://doi.org/10.1016/j.march em.2004.03.007

21. Varol M (2011) Assessment of heavy metal contamination in sediments of the tigris river (Turkey) using pollution indices and multivariate statistical techniques. J Hazard Mater 195:355-364. https://doi.org/10.1016/j.jhazmat.2011.08.051

22. Artigas F, Loh JM, Shin JY, Grzyb J, Yao Y (2017) Baseline and distribution of organic pollutants and heavy metals in tidal creek sediments after Hurricane Sandy in the Meadowlands of New Jersey. Environ Earth Sci 76(7):293. https://doi.org/10.1007/ s12665-017-6604-y

23. Shin JY, Artigas F, Hobble C, Lee Y-S (2013) Assessment of anthropogenic influences on surface water quality in urban estuary, northern New Jersey: multivariate approach. Environ Monit Assess 185(3):2777-2794. https://doi.org/10.1007/s1066 1-012-2748-0

24. Mattson C, Potera G, Saks ME (1971) Water quality in a disordered ecosystem: A report on the water quality monitoring study performed in the Hackensack Meadowlands between June and September. Hackensack Meadowlands Development Commission, Lyndhurst

25. Carswell LD (1976) Appraisal of water resources in the Hackensack River Basin, New Jersey. U.S. Geological Survey-Water Resources Investigations Report 
26. USACE, USEPA (1995) Draft Environmental Impact Statement on the Special Area Management Plan (SAMP)

27. USACE (2005) Draft Meadowlands Comprehensive Restoration Implementation Plan (MCRIP): Hudson-Raritan Estuary, Hackensack Meadowlands, New Jersey. New York District, New York, NY

28. US Army Corps of Engineers (1997) Handbook for the preparation of storm water pollution prevention plans for construction activities. vol Pamphlet \# 1110-1-16. Washington, DC

29. EPA (1999) Storm Phase II Proposed Rule. Construction site runoff control. Minimum control measures. EPA Office of Water

30. Wang Q, Li Y, Wang Y (2011) Optimizing the weight loss-onignition methodology to quantify organic and carbonate carbon of sediments from diverse sources. Environ Monit Assess 174:241-257. https://doi.org/10.1007/s10661-010-1454-z

31. EPA (2007) Method 3051A (SW-846): Microwave Assisted Acid Digestion of Sediments, Sludges, and Oils. vol vol Revision 1. Washington, DC

32. Berry's Creek Study Area Cooperating PRP Group (2016) Remedial Investigation Report; Berry' Creek Study Area Remedial Investigation

33. Bouezmarni M, Wollast R (2005) Geochemical composition of sediments in the Scheldt estuary with emphasis on trace metals. Hydrobiologia 540(1):155-168. https://doi.org/10.1007/s1075 0-004-7131-x

34. Hong YS, Kinney KA, Reible DD (2011) Effects of cyclic changes in $\mathrm{pH}$ and salinity on metals release from sediments. Environ Toxicol Chem 30(8):1775-1784. https://doi.org/10.1002/etc.584

35. Teal JM (1996) Salt marshes: they offer diversity of habitat. Oceanus 39:13
36. Soil Survey Staff (2020) Natural Resources Conservation Service, United States Department of Agriculture. Soil Series Classification Database. https://www.nrcs.usda.gov/wps/portal/nrcs/ detail/soils/survey/class/data/?cid=nrcs142p2_053583

37. Johnston SG, Keene AF, Bush RT, Burton ED, Sullivan LA, Isaacson $L$, McElnea AE, Ahern CR, Smith CD, Powell $B$ (2011) Iron geochemical zonation in a tidally inundated acid sulfate soil wetland. Chem Geol 280(3):257-270. https://doi.org/10.1016/j. chemgeo.2010.11.014

38. Mao H, Ye Z, Driscoll C (2017) Meteorological effects on Hg wet deposition in a forested site in the Adirondack region of New York during 2000-2015. Atmos Environ 168:90-100. https://doi. org/10.1016/j.atmosenv.2017.08.058

39. Reinfelder JR, Janssen SE (2019) Tracking legacy mercury in the Hackensack River estuary using mercury stable isotopes. J Hazard Mater 375:121-129. https://doi.org/10.1016/j.jhazm at.2019.04.074

40. Long ER, MacDonald DD, Smith SL, Calder FD (1995) Incidence of adverse biological effects within ranges of chemical concentrations in marine and estuarine sediments. Environ Manage 19(1):81-97

Publisher's Note Springer Nature remains neutral with regard to jurisdictional claims in published maps and institutional affiliations. 